\title{
In vivo oxidation of the methyl group of hepatic 5-methyltetrahydrofolate
}

\author{
M LUMB, I CHANARIN, R DEACON, J PERRY \\ From the Haematology Section, Medical Research Council Clinical Research Centre, Northwick Park Hospital, \\ Harrow, Middlesex
}

SUMMARY Methionine given parenterally to rats caused rapid disappearance of methyltetrahydrofolate from the liver and a corresponding rise in tetrahydrofolate and formyl-tetrahydrofolate concentrations. When $\left[{ }^{14} \mathrm{C}\right] \mathrm{H}_{3}-\mathrm{H}_{4}$ folate was given, methionine caused an increased $\left[{ }^{14} \mathrm{C}\right] \mathrm{O}_{2}$ excretion, indicating that oxidation of the methyl group had occurred. Methionine was more effective than Sadenosylmethionine at causing oxidation, but serine was ineffective.

The lowest dose of methionine to produce an effect was $0.5 \mu \mathrm{mol}$, which is less than the daily dietary intake in a rat. The data suggest that the concentration of methylfolate in rat livers is controlled by the concentrations of methionine.

Folic acid functions in the transfer of single carbon units. These are formyl (CHO-) required for purine synthesis, methylene $\left(-\mathrm{CH}_{2}-\right)$ required for thymidine synthesis, and methyl $\left(-\mathrm{CH}_{3}-\right)$ required for methionine synthesis. 5-methyltetrahydrofolate (5- $\mathrm{Ch}_{3}-\mathrm{H}_{4} \mathrm{PteGlu}$, methylfolate) is also the form in which natural folates are absorbed from the gut into portal blood. It is also the dominant analogue in plasma and the only form of folate in the cerebrospinal fluid. The manner in which methylfolate is formed and metabolised is central to understanding the interaction between cobalamin and folate, and these aspects have been reviewed.'

5-Methyl-tetrahydrofolate is formed by reduction of 5,10-methylenetetrahydrofolate. The enzyme is 5,10-methylenetetrahydrofolate reductase, and in vitro the reaction is noticeably shifted in the direction of methylfolate synthesis. On the basis of in vitro studies the reverse reaction, involving oxidation of methylfolate, is regarded as unlikely.

The methyl group of $5-\mathrm{CH}_{3}-\mathrm{H}_{4}$ PteGlu is transferred to homocysteine by methionine synthetase in the de novo synthesis of methionine. This is said to be the only means for the disposal of the methyl group of methylfolate. Failure of the methionine synthetase reaction, which occurs in cobalamin deficiency or in cobalamin inactivation by nitrous oxide, may lead to accumulation of $5-\mathrm{CH}_{3}-\mathrm{H}_{4} \mathrm{PteGlu}$ and subsequent "trapping" of folate. This has been termed the methylfolate trap hypothesis. ${ }^{23}$

Accepted for publication 19 May 1988
When these ideas were put forward, ${ }^{3}$ it was also noted that methionine had considerable effects on the distribution of folate analogues in rat livers. The authors found that $1 \%$ methionine added to the rat diet and fed for 24 hours before sacrifice considerably increased the amount of tetrahydrofolate and formyl tetrahydrofolate at the expense of methyltetrahydrofolate. This occurred in both control and experimental animals. The mechanism of this redistribution was not established, although it was conjectured that methionine might provide a methyl group acceptor via S-adenosylhomocysteine derived from demethylation of S-adenosylmethionine.

The effect of methionine in lowering $\mathrm{CH}_{3}-\mathrm{H}_{4}$ PteGlu and increasing $\mathrm{H}_{4} \mathrm{PteGlu}$ and $\mathrm{CHO}-\mathrm{H}_{4}$ PteGlu concentrations in liver has been confirmed most recently by Brody et al, who showed that $300 \mu \mathrm{mol}$ of methionine in the rat virtually removed all hepatic methylfolate within 30 minutes. They too did not comment on how this occurred. They used cobalamininactivated rats so that the methyl group could not have been passed on to homocysteine. ${ }^{4}$

S-adenosylmethionine in vitro inhibits the activity of the enzyme methylene tetrahydrofolate reductase and so inhibits further synthesis of methylfolate. On this basis the concentration of S-adenosylmethionine has been assumed to be the main regulatory factor in the rate of methylfolate synthesis.

The validity of these views are of importance in understanding folate and one-carbon unit metabolism and how cobalamin deficiency produces its effects. The purpose of this study was to explore how methionine and related compounds changed the concentrations of 1158 
methylfolate in rat livers, and in particular to obtain evidence for the in vivo oxidation of the methyl group of methylfolate to formate and carbon dioxide.

\section{Material and methods}

Methionine, 5-deoxy-5'-methylthioadenosine, glycine, serine and betaine were obtained from Sigma. Sodium formate was obtained from Koch Light. Sadenosylmethionine was generously donated by Dr G Stramentinoli of Bioresearch, Milan.

Male Sprague-Dawley rats weighing between 80 and $120 \mathrm{~g}$ were used. Animals were given the compounds in a standard volume of $0.5 \mathrm{ml}$ in water by intraperitoneal injection. Thirty minutes later, animals were killed, livers removed and heated for five minutes in 20 volumes of $1 \%$ ascorbic acid $(\mathrm{pH} 7)$ at $95^{\circ} \mathrm{C}$. Samples were then cooled, homogenised, and stored at $-20^{\circ} \mathrm{C}$.

\section{IDENTIFICATION OF FOLATES}

Liver homogenates were treated with $\gamma$-glutamyl carboxypeptidase prepared from pig kidney. Homogenate $(0.1 \mathrm{~g})$ was adjusted to $\mathrm{pH} 4.5$ and incubated with $1.5 \mathrm{ml}$ of enzyme preparation for five hours at $37^{\circ} \mathrm{C}$, then diluted to $10 \mathrm{ml}$ in $0 \cdot 1 \mathrm{M}$ sodium phosphate buffer (pH 5.7).

After centrifugation at $3000 \times g$ for 30 minutes the supernatant was applied to a column of DEAE cellulose (Whatman DE52). Folate monoglutamates were separated using a non-linear salt gradient. The mixing chamber contained $150 \mathrm{ml}$ of $0.1 \mathrm{M}$ potassium phosphate (pH 6.0), to which was added 0.2M 2mercaptoethanol. The reservoir contained $350 \mathrm{ml}$ of $1.0 \mathrm{M}$ potassium phosphate $(\mathrm{pH} \mathrm{6.0)}$ with $0.2 \mathrm{M} 2$ mercaptoethanol. Fractions $(5 \mathrm{ml})$ were collected, all the folates eluting before fraction 50 . Folates were identified by elution postion and measured by microbiological assay with Lactobactillus casei (NCIMB 8081). 5-CHO- $\mathrm{H}_{4}$ PteGlu was measured using Pediococcus cerevisiae (NCIMB 7837)). As 5formyl- and 5-methyl- $\mathrm{H}_{4}$ PteGlu elute very close together and 5-methyl- $\mathrm{H}_{4} \mathrm{PteGlu}$ is inactive for $\boldsymbol{P}$ cerevisiae, $\boldsymbol{P}$ cerevisiae assay was used as a measure of 5-formylfolate.

Amounts of each folate were expressed as the percentage of the total folate.

\section{$\left[{ }^{14} \mathrm{C}\right] \mathrm{O}_{2}$ PRODUCTION}

$5-\left[{ }^{14} \mathrm{C}\right] \mathrm{H}_{3}-\mathrm{H}_{4}$ PteGlu specific activity $60 \mathrm{mCi} / \mathrm{mmol}$, was obtained from Amersham Internation. Ten Sprague Dawley rats were exposed to $\mathrm{N}_{2} \mathrm{O} / \mathrm{O}_{2}(1 / 1)$ in a specially constructed perspex chamber. After four days half the rats were given an intraperitoneal injection containing $300 \mu \mathrm{mol}$ of methionine and $2 \mu \mathrm{Ci}$ $5-\left[{ }^{14} \mathrm{C}\right] \mathrm{H}_{3}-\mathrm{H}_{4}$ PteGlu alone. The animals were then placed in individual chambers through which nitrous oxide and oxygen continued to be passed. Expired carbon dioxide was collected by passing the outflow from the chambers through two vessels connected in series, each containing $50 \mathrm{ml}$ of $2 \mathrm{M}$ potassium hydroxide. The efficiency of this system was checked by passing the outflow of the second vessel through a solution of barium hydroxide $(50 \mathrm{~g} / \mathrm{l})$. No precipitate was formed. One ml samples of the potassium hydroxide were taken every hour into $10 \mathrm{ml}$ NE260 (Nuclear Enterprises) and counted on a LKB Betarak liquid scintillation counter. Quench corrections were made by the channels ratio method using an external standard.

\section{Results}

PRODUCTION OF $\left[{ }^{14} \mathrm{C}\right] \mathrm{O}_{2}$ FROM $\left[{ }^{14} \mathrm{C}\right] \mathrm{H}_{3}-\mathrm{H}_{4}$ PTEGLU Rats given $\left[{ }^{14} \mathrm{C}\right] \mathrm{H}_{3}-\mathrm{H}_{4}$ PteGlu exhaled $\left[{ }^{14} \mathrm{C}\right] \mathrm{O}_{2}$, reaching a peak at two hours after the dose of methylfolate. When this was accompanied by an injection of 300 $\mu \mathrm{mol}$ of methionine the total $\left[{ }^{14} \mathrm{C}\right] \mathrm{O}_{2}$ excretion was greater (fig 1), reaching a peak at three hours, and this difference was significant at the $5 \%$ level.

\section{EFFECT OF METHIONINE OF FOLATE ANALOGUES} IN LIVER

The distribution of $\mathrm{CH}_{3}-\mathrm{H}_{4} \mathrm{PteGlu}, \mathrm{CHO}-\mathrm{H}_{4}$ PteGlu, and $\mathrm{H}_{4}$ PteGlu in rat livers is shown in table 1 and fig 2 . Methionine $(0.5 \mu \mathrm{mol})$ produced a fall in the methylfolate concentrations from $45 \%$ to $36 \%$, and the maximum decline to $2.6 \%$ was reached with a 50 $\mu$ mol dose. The fall in the $\mathrm{CH}_{3}-\mathrm{H}_{4}$ PteGlu concentra-

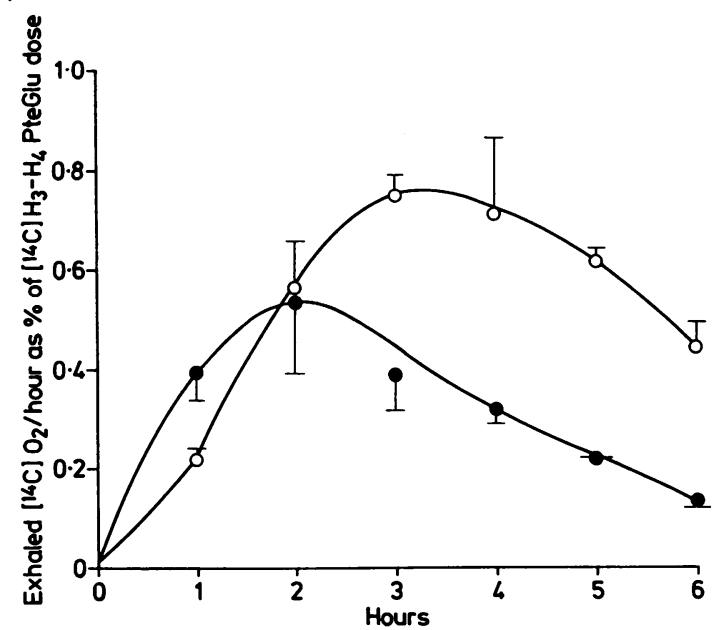

Fig 1 Two groups of five rats breathing $\mathrm{N}_{2} \mathrm{O} / \mathrm{O}_{2}(1 / 1)$ for three days were given an injection of $\left[{ }^{14} \mathrm{C}\right] \mathrm{H}_{3}-\mathrm{H}^{4} \mathrm{PteGlu}$. One group (0) was given 300 umol methionine intraperitoneally at the same time. Exhaled $\left[{ }^{14} \mathrm{C}\right] \mathrm{O}_{2}$ was collected into potassium hydroxide. 
Table 1 Effect of parenteral methionine on percentage of folate analogues present in rat liver

\begin{tabular}{|c|c|c|c|c|c|c|c|c|c|}
\hline \multirow{2}{*}{$\begin{array}{l}\text { Dose } \\
\text { of } \\
\text { methionine } \\
\text { ( } \mu \text { mol) }\end{array}$} & \multicolumn{3}{|c|}{$\mathrm{CH}_{5}-\mathrm{H}_{4}$ PteGlu } & \multicolumn{3}{|c|}{$\mathrm{CHO}-\mathrm{H}_{\triangleleft}$ PteGlu } & \multicolumn{3}{|c|}{ H,PteGlu } \\
\hline & $(n=)$ & $\begin{array}{l}\text { Mean } \\
(S D)\end{array}$ & Range & $(n=)$ & $\begin{array}{l}\text { Mean } \\
\text { (SD) }\end{array}$ & Range & $(n=)$ & $\begin{array}{l}\text { Mean } \\
\text { (SD) }\end{array}$ & Range \\
\hline $\begin{array}{l}0 \\
0.5 \\
1.0 \\
4 \cdot 0 \\
8.0 \\
16 \cdot 0 \\
50 \cdot 0 \\
100 \cdot 0 \\
300 \cdot 0\end{array}$ & $\begin{array}{r}16 \\
3 \\
3 \\
6 \\
6 \\
6 \\
3 \\
3 \\
3\end{array}$ & $\left\{\begin{array}{l}45.0(7.0) \\
35.7(4.2) \\
27.3(5.7) \\
28.8(10.1) \\
23.8(5.5) \\
16.6(7.9) \\
2.6(1.5) \\
2.8(0.5) \\
2.9(0.3)\end{array}\right.$ & $\begin{array}{l}36 \cdot 4-56 \cdot 7 \\
31 \cdot 6-39 \cdot 9 \\
21 \cdot 6-33 \cdot 0 \\
14 \cdot 5-44 \cdot 3 \\
15 \cdot 6-31 \cdot 8 \\
10 \cdot 1-31 \cdot 4 \\
1 \cdot 0-4 \cdot 0 \\
2 \cdot 4-3 \cdot 3 \\
2 \cdot 6-3 \cdot 1\end{array}$ & $\begin{array}{r}16 \\
3 \\
3 \\
6 \\
6 \\
6 \\
3 \\
3 \\
3\end{array}$ & $\begin{array}{l}23.5(3.6) \\
28.6(2.6) \\
30.8(3.2) \\
32.0(5 \cdot 8) \\
33.5(3.8) \\
40.5(5.2) \\
42.3(4 \cdot 3) \\
44.3(2 \cdot 7) \\
46.7(3.1)\end{array}$ & $\begin{array}{l}17 \cdot 8-28 \cdot 6 \\
26 \cdot 9-31 \cdot 6 \\
27 \cdot 6-34 \cdot 0 \\
22 \cdot 1-40 \cdot 5 \\
26 \cdot 4-37 \cdot 0 \\
30 \cdot 1-44 \cdot 0 \\
37 \cdot 4-45 \cdot 6 \\
42 \cdot 4-47 \cdot 5 \\
44 \cdot 2-50 \cdot 2\end{array}$ & $\begin{array}{r}16 \\
3 \\
3 \\
6 \\
6 \\
6 \\
3 \\
3 \\
3\end{array}$ & $\begin{array}{l}31.5(5 \cdot 7) \\
35.7(5 \cdot 1) \\
41.9(5 \cdot 0) \\
39.2(10.6) \\
42.7(4 \cdot 1) \\
42.9(4 \cdot 3) \\
55 \cdot 1(3 \cdot 0) \\
52.9(2 \cdot 5) \\
50.4(2.9)\end{array}$ & $\begin{array}{l}22 \cdot 1-39 \cdot 0 \\
32 \cdot 7-41 \cdot 5 \\
38 \cdot 7-47 \cdot 6 \\
22 \cdot 8-53 \cdot 7 \\
39 \cdot 2-50 \cdot 5 \\
38 \cdot 1-47 \cdot 5 \\
53 \cdot 3-58 \cdot 6 \\
50 \cdot 1-55 \cdot 0 \\
47 \cdot 2-52 \cdot 7\end{array}$ \\
\hline
\end{tabular}

*Value is significantly less than in group not given methionine.

tion was accompanied by a parallel increase in $\mathrm{CHO}-\mathrm{H}_{4}$ PteGlu and $\mathrm{H}_{4}$ PteGlu (table 1 and fig 3), implying oxidation of the methyl groups to formyl and carbon dioxide (fig 1).

\section{EFFECT OF S-ADENOSYLMETHIONINE ON FOLATE}

ANALOGUES IN LIVER

S-adenosylmethionine was far less effective on a molar basis then methionine in producing a fall in methylfolate analogues (table 2 and fig 4). The rate of decline of methylfolate with increasing doses of S-adenosylmethionine paralleled that achieved with methionine, and suggested that the effect of S-adenosylmethionine

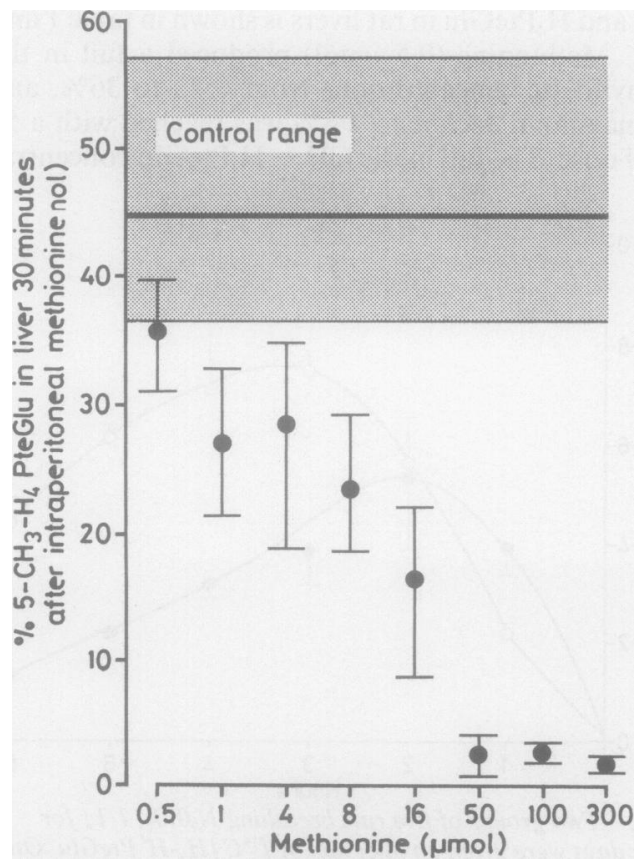

Fig 2 Fall in the concentration of $5-\mathrm{CH}_{3}-\mathrm{H}_{4}$ PteGlu in rat liver in animals killed 30 minutes after an intraperitoneal dose of methionine. Dose of methionine varied from 0.5 to $300 \mu \mathrm{mol}$. was caused by methionine which had been regenerated after further metabolism of S-adenosylmethionine.

\section{EFFECT OF 5'-METHYLTHIOADENOSINE ON}

FOLATE ANALOGUES IN LIVER

This compound, derived from decarboxylated S-adenosylmethionine via synthesis of polyamines, is metabolised back to methionine with release of a formate unit. At a dose of $16 \mu \mathrm{mol} 5$ '-methylthioadenosine produced a fall of $30 \%$ in methylfolate concen-

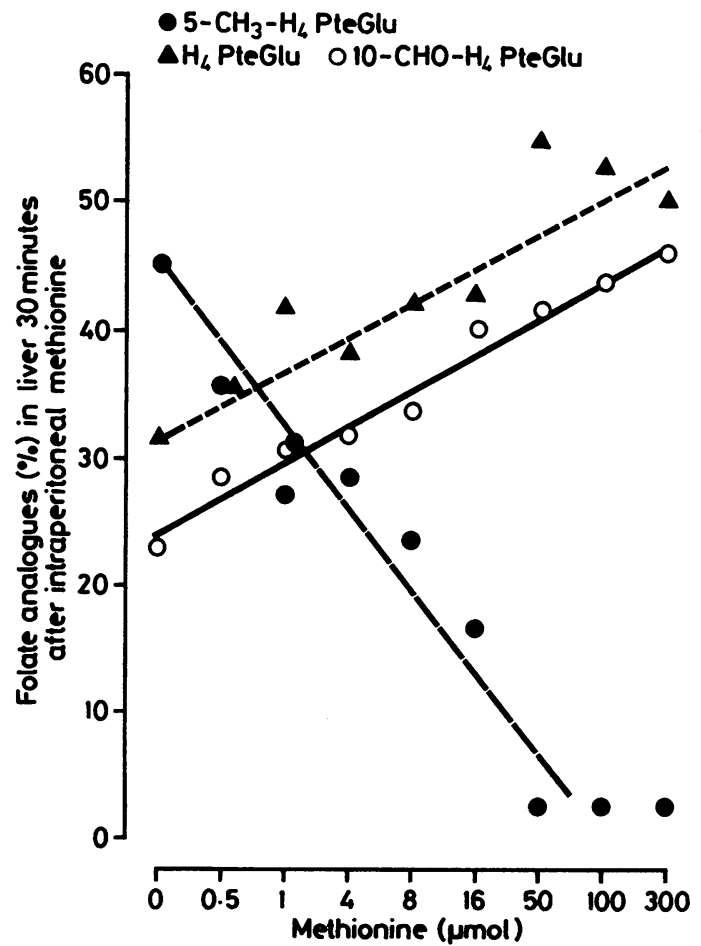

Fig 3 Mean fall in the concentration of $5-\mathrm{CH}_{3}-\mathrm{H}_{4} \mathrm{PteGlu}$ in rat liver after methionine and concomitant rise in the concentration of $\mathrm{H}_{4}$ PteGlu and $\mathrm{CHO}-\mathrm{H}_{4}$ PteGlu. 
Table 2 Effect of parenteral S-adenosylmethionine on percentage of folate analogues present in rat liver

\begin{tabular}{|c|c|c|c|c|c|c|c|c|c|}
\hline \multirow{2}{*}{$\begin{array}{l}\text { Dose of } \\
\text { S-adenosyl- } \\
\text { methionine } \\
(\text { (umol })\end{array}$} & \multicolumn{3}{|c|}{$\mathrm{CH}_{3}-\mathrm{H}_{4}$ PteGlu } & \multicolumn{3}{|c|}{ CHO-H,PteGlu } & \multicolumn{3}{|c|}{ H,PteGlu } \\
\hline & $(n=)$ & $\begin{array}{l}\text { Mean } \\
(S D)\end{array}$ & Range & $(n=)$ & $\begin{array}{l}\text { Mean } \\
(S D)\end{array}$ & Range & $(n=)$ & $\begin{array}{l}\text { Mean } \\
\text { (SD) }\end{array}$ & Range \\
\hline $\begin{array}{r}0 \\
31 \\
97 \\
194\end{array}$ & $\begin{array}{r}16 \\
6 \\
3 \\
3\end{array}$ & $\begin{array}{l}45 \cdot 0(7 \cdot 0) \\
32 \cdot 3^{*}(6 \cdot 5) \\
28 \cdot 0^{*}(4 \cdot 7) \\
23 \cdot 7^{*}(5 \cdot 6)\end{array}$ & $\begin{array}{l}36 \cdot 4-56 \cdot 7 \\
25 \cdot 1-42.9 \\
21 \cdot 7-35 \cdot 0 \\
18 \cdot 9-29 \cdot 9\end{array}$ & $\begin{array}{r}16 \\
6 \\
6 \\
3\end{array}$ & $\begin{array}{l}23 \cdot 5(3 \cdot 6) \\
32 \cdot 2(6 \cdot 2) \\
33 \cdot 1(2 \cdot 7) \\
28 \cdot 4(1 \cdot 3)\end{array}$ & $\begin{array}{l}17 \cdot 8-28 \cdot 6 \\
23 \cdot 4-38 \cdot 0 \\
30 \cdot 2-37 \cdot 6 \\
26 \cdot 9-29 \cdot 3\end{array}$ & $\begin{array}{r}16 \\
6 \\
6 \\
3\end{array}$ & $\begin{array}{l}31 \cdot 5(5.7) \\
35 \cdot 5(4.9) \\
38.9(2.7) \\
47.9(6.5)\end{array}$ & $\begin{array}{l}22 \cdot 1-39 \cdot 0 \\
30 \cdot 1-43 \cdot 1 \\
33 \cdot 7-40 \cdot 7 \\
41 \cdot 2-54 \cdot 2\end{array}$ \\
\hline
\end{tabular}

*Value is significantly less than in group not given $\mathrm{S}$-adenosylmethionine.

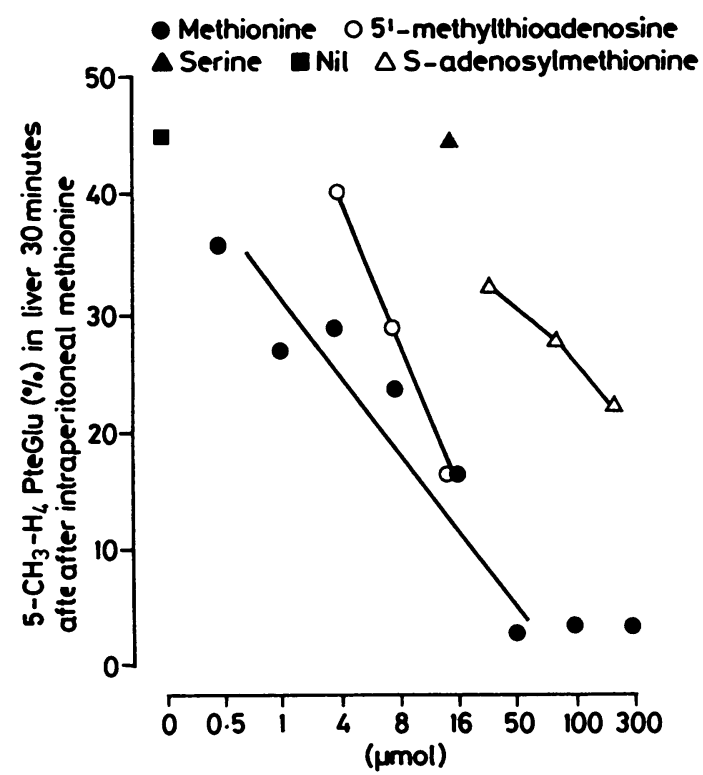

Fig 4 Mean fall in the concentration of $5-\mathrm{CH}_{3}-\mathrm{H}_{4}$ PteGlu in rat liver after methionine, $S$-adenosylmethionine, 5 'methylthioadenosine and serine.

trations (table 3 and fig 4). Due to toxicity of 5'methylthioadenosine, doses greater than $16 \mu \mathrm{mol}$ were not tested.

EFFECT OF OTHER COMPOUNDS ON FOLATE

ANALOGUES IN LIVER

Neither serine nor formate (table 4 and fig 4) had any effect on methylfolate concentrations in liver but both glycine and betaine had an effect that was comparable with an equimolar dose of S-adenosylmethionine.

\section{Discussion}

Kutzbach and Stokstad suggested that the concentration of methylfolate in liver is regulated by control of the rate of its synthesis. ${ }^{5}$ S-adenosylmethionine inhibited the acitivity of methylenetetrahydrofolate reductase which reduces methylene- $\mathrm{H}_{4}$ PteGlu to methyl- $\mathrm{H}_{4} \mathrm{PteGlu}$. Our data suggest that the concentration of methylfolate in liver is more finely attuned to that of methionine. Excess methionine is toxic and its increase leads to rapid conversion of the methyl group of methylfolate to more oxidised forms, and presumably to the end of methionine synthesis. This oxidation occurs in both $B_{12}$-deficient ${ }^{2}$ and $B_{12}$-inactivated animals (unpublished observations) as well as in healthy animals. The amount of methionine producing this effect can be as little as $0.5 \mu \mathrm{mol}$, which is well below the normal daily intake in a rat. S-adenosylmethionine was less effective than methionine and suggests that $\mathrm{S}$-adenosylmethionine concentrations are less important than methionine in regulating methylfolate metabolism. Indeed, the activity of Sadenosylmethionine was related to the amount of methionine regenerated.

The data have implications for the methylfolate trap hypothesis, which assumes that the methyl group of methylfolate is not oxidised. Even in the absence of a methionine supplement the $B_{12}$-inactivated animal is able to dispose of the methyl group of methylfolate by

Table 3 Effect of parenteral $5^{\prime}$-methylthioadenosine on percentage of folate analogues present in rat liver

\begin{tabular}{|c|c|c|c|c|c|c|c|c|c|}
\hline \multirow{2}{*}{$\begin{array}{l}\text { Dose } \\
\text { of } \\
M T A \\
(\mu \mathrm{mol})\end{array}$} & \multicolumn{3}{|c|}{$\mathrm{CH}_{3}-\mathrm{H}_{4}$ PteGlu } & \multicolumn{3}{|c|}{$\mathrm{CHO}-\mathrm{H}_{4}$ PteGlu } & \multicolumn{3}{|c|}{ H,PteGlu $_{4}$} \\
\hline & $(n=)$ & $\begin{array}{l}\text { Mean } \\
(S D)\end{array}$ & Range & $(n=)$ & $\begin{array}{l}\text { Mean } \\
\text { (SD) }\end{array}$ & Range & $(n=)$ & $\begin{array}{l}\text { Mean } \\
\text { (SD) }\end{array}$ & Range \\
\hline $\begin{array}{r}0 \\
4 \\
8 \\
16\end{array}$ & $\begin{array}{r}16 \\
3 \\
3 \\
3\end{array}$ & $\begin{array}{l}45 \cdot 0(7 \cdot 0) \\
40.0(4 \cdot 9) \\
28 \cdot 4^{*}(3 \cdot 3) \\
15 \cdot 6^{*}(6 \cdot 2)\end{array}$ & $\begin{array}{l}36 \cdot 4-56 \cdot 7 \\
36 \cdot 3-45 \cdot 6 \\
25 \cdot 1-31 \cdot 6 \\
8 \cdot 5-19 \cdot 3\end{array}$ & $\begin{array}{r}16 \\
3 \\
3 \\
3\end{array}$ & $\begin{array}{l}23.5(3.6) \\
22.6(4.2) \\
26.6(1.3) \\
34.1(2.4)\end{array}$ & $\begin{array}{l}17 \cdot 8-28 \cdot 6 \\
18 \cdot 9-27 \cdot 1 \\
25 \cdot 2-27 \cdot 7 \\
31 \cdot 7-36 \cdot 5\end{array}$ & $\begin{array}{r}16 \\
3 \\
3 \\
3\end{array}$ & $\begin{array}{l}31.5(5.7) \\
37.4(2.4) \\
45.0(3.8) \\
50.3(4.2)\end{array}$ & $\begin{array}{l}22 \cdot 1-39 \cdot 0 \\
35 \cdot 5-40 \cdot 1 \\
40 \cdot 7-47 \cdot 9 \\
46 \cdot 8-55 \cdot 0\end{array}$ \\
\hline
\end{tabular}

*Value is significantly less than in group not given methylthioadenosine. 
Table 4 Effect of parenteral glycine, serine, betaine and formate given at a dose of 16 umol on percentage of folate analogues present in rat liver

\begin{tabular}{|c|c|c|c|c|c|c|c|c|c|}
\hline \multirow[b]{2}{*}{ Compound } & \multicolumn{3}{|c|}{$\mathrm{CH}_{3}-\mathrm{H}_{4}$ PteGlu } & \multicolumn{3}{|c|}{$\mathrm{CHO}-\mathrm{H}_{4}$ PteGlu } & \multicolumn{3}{|c|}{$H_{\triangleleft}$ PteGlu } \\
\hline & $(n=)$ & $\begin{array}{c}\text { Mean } \\
(S D)\end{array}$ & Range & $(n=)$ & $\begin{array}{l}\text { Mean } \\
(S D)\end{array}$ & Range & $(n=)$ & $\begin{array}{l}\text { Mean } \\
(S D)\end{array}$ & Range \\
\hline $\begin{array}{l}0 \\
\text { Glycine } \\
\text { Serine } \\
\text { Betaine } \\
\text { Formate }\end{array}$ & $\begin{array}{r}16 \\
6 \\
3 \\
6 \\
3\end{array}$ & $\begin{array}{l}45 \cdot 0(7 \cdot 0) \\
31 \cdot 2 *(7 \cdot 2) \\
44 \cdot 2(3 \cdot 1) \\
34 \cdot 0 *(9 \cdot 6) \\
39 \cdot 4(8 \cdot 22)\end{array}$ & $\begin{array}{l}36 \cdot 4-56 \cdot 7 \\
24 \cdot 5-40 \cdot 7 \\
41 \cdot 7-47 \cdot 7 \\
24 \cdot 1-47 \cdot 2 \\
31 \cdot 6-48 \cdot 0\end{array}$ & $\begin{array}{r}16 \\
6 \\
3 \\
3 \\
3\end{array}$ & $\begin{array}{l}23.5(3.6) \\
28.6(5 \cdot 5) \\
17 \cdot 4(0.9) \\
28.5(7.4) \\
27.7(5.2)\end{array}$ & $\begin{array}{l}17 \cdot 8-28 \cdot 6 \\
19 \cdot 8-34 \cdot 8 \\
16 \cdot 8-18 \cdot 4 \\
17 \cdot 1-36 \cdot 0 \\
22 \cdot 5-32 \cdot 8\end{array}$ & $\begin{array}{r}16 \\
6 \\
3 \\
3 \\
3\end{array}$ & $\begin{array}{l}31 \cdot 5(5 \cdot 7) \\
40 \cdot 2(4 \cdot 7) \\
38 \cdot 4(2 \cdot 5) \\
37 \cdot 5(6 \cdot 1) \\
32.9(3 \cdot 1)\end{array}$ & $\begin{array}{l}22 \cdot 1-39 \cdot 0 \\
33 \cdot 8-45 \cdot 3 \\
35 \cdot 5-39 \cdot 9 \\
30 \cdot 1-48 \cdot 4 \\
29 \cdot 5-35 \cdot 6\end{array}$ \\
\hline
\end{tabular}

-Value is significantly less than in group not given either glycine nor betaine.

oxidation. ${ }^{6}$ This is enhanced considerably by raising the methionine intake.

Accumulation of methylfolate occurs in $B_{12}$-inactivation, primarily because of the failure of the methionine synthetase reaction. The hepatic concentration of methylfolate reaches its peak within hours of exposure to nitrous oxide but thereafter falls and remains at a plateau after seven days. This methylfolate is metabolically active in so far as it serves as a substrate for the synthesis of polyglutamate with up to five glutamic acid residues. The absence of methylhexaglutamate has suggested oxidation of the methyl group from the hexaglutamate in accordance with the observations of Brody, Watson, and Stokstad. ${ }^{4}$ Addition of a methionine supplement is accompanied by oxidation of methylfolate within minutes, so that it seems unlikely that this occurs from methylhexaglutamate alone but probably from methylfolates of variable chain length, including monoglutamates.

The confirmation of the in vivo oxidation of the methyl group of methylfolate in both healthy and $B_{12}$-inactivated animals removes one of the central pivots of the methylfolate trap hypothesis. There are other equally important observations, however, that are not accounted for by methylfolate trapping.' Firstly, the most important is the failure of $B_{12}$-deficient or $B_{12}$-inactivated cells to use $\mathrm{H}_{4}$ PteGlu in a normal manner. Thus $\mathrm{H}_{4} \mathrm{PteGlu}$ failed to correct the defect in the dU suppression test in marrow cells from patients with untreated pernicious anaemia. This was confirmed with rat marrow from animals exposed to nitrous oxide. Further $\mathrm{H}_{4}$ PteGlu was not used as substrate for folate polyglutamate synthesis in liver in rats exposed overnight to nitrous oxide.

Secondly, the impairment of both thymidine synthesis in the $\mathrm{dU}$ suppression test and of folate polyglutamate synthesis in the $B_{12}$-inactivated rat was reversed completely if folate carrying a carbon unit at the formate level of oxidation was provided. The most convenient was 5-formyl-tetrahydrofolate, but 10formyl-tetrahydrofolate and 5,10-methenyl-tetrahydrofolate were equally effective.
Thirdly, the defects due to $\mathrm{B}_{12}$-inactivation were reversed by supplying a compound that yielded formate. The most interesting was 5'-methylthioadenosine, which is derived from S-adenosylmethionine and is reconverted to methionine, yielding a mole of formate for each mole methionine regenerated. This compound was much more effective than methionine itself in reversing the effects of $B_{12}$ deficiency.

We therefore suggest that the effect of $B_{12}$ deficiency is a lack of active formate which is normally derived directly from methionine and indirectly through Sadenosylmethionine and 5'-methylthioadenosine.

These studies reported here are in part fulfilment of the requirements for the Fellowship of the Institute of Medical Laboratory Sciences.

\section{References}

1 Chanarin I, Deacon R, Lumb M, Muir M, Perry J. Cobalaminfolate interrelations: a critical review. Blood 1985;66:479-89.

2 Noronha JM, Silverman M. On folic acid, vitamin $B_{12}$, methionine and formiminoglutamic acid. In: Heinrich HC, ed. Vitamin $B_{12}$ and intrinsic factor 2. Europaisches Symposium. Stuttgart: Enke, 1962:728-36.

3 Herbert V, Zalusky R. Interrelationship of vitamin $B_{12}$ and folic acid metabolism: folic acid clearance studies. $J$ Clin Invest 1962;41:1263-76.

4 Brody T, Watson JE, Stokstad ELR. Folate pentaglutamate and folate hexaglutamate mediated one-carbon metabolism. Biochemistry 1982;21:276-82.

5 Kutzbach C, Stokstad ELR. Mammalian methylenetetrahydrofolate reductase. Partial purification, properties and inhibition by S-adenosylmethionine. Biochem Biophys Acta 1971;250:459-77.

6 Lumb M, Chanarin I, Perry J, Deacon R. Turnover of the methyl moiety of 5-methyltetrahydropteroylglutamic acid in the cobalamin-inactivated rat. Blood 1985;66:1171-5.

Requests for reprints to: Dr I Chanarin, Clinical Research Centre, Watford Road, Harrow, Middlesex HAl 3UJ, England. 